\title{
THE CONCEPT FOR THE DEVELOPMENT \\ OF A FUNCTIONAL AREA ILLUSTRATED \\ BY THE CASE OF THE FUNCTIONAL \\ AREA OF THE OdER COMMUNES
}

\author{
ANETTA BARSKA, JANINA JĘDRZEJCZAK-GAS
}

\begin{abstract}
A B S T R A C T
The aim of this article is to present the essence of a functional area as a new tool of the EU regional policy and the course of designing an integrated approach to the development of the functional area. The study is a case study and relates to the methodical process of creating a development concept for the Functional Area of Oder Communes (FAOC). This article is based on the analysis of the domestic and foreign literature on regional development and own experiences and reflections of authors resulting from the work in the team for the development of a strategy for this area.

The analysis of domestic and foreign literature allowed for presenting a new paradigm of the local development. The current approach is characterized by a focus on the use of endogenous potentials and territorial targeting of the development, which promotes the creation of functional and spatial structures such as functional areas. Their development requires integrated development planning that provides benefits both in the social and economic dimension. The study presents the new paradigm of the local development in the context of the National Spatial Development Concept 2030. The study presents the theoretical and practical basis for creating a concept for integrated development of a functional area.
\end{abstract}

KEY WORDS

functional area, regional policy, spatial policy, local development, development concept

DOI: 10.1515/emj-2016-0021
Corresponding author:

Anetta Barska

Faculty of Economics and Management, University of Zielona Góra

e-mail: A.Barska@wez.uz.zgora.pl

Janina Jędrzejczak-Gas

Faculty of Economics and Management, University of Zielona Góra

e-mail: J.Jedrzejczak-Gas@wez.uz. zgora.pl

\section{INTRODUCTION}

The contemporary public administration should not be concentrated only on the issues related to the provision of public services but rather on the effective management, which can be reflected in the creation of new functional spatial structures and concepts of their integrated development aiming at building a sustainable competitive advantage.
The aim of this article is to present the essence of a functional area as a new tool of the EU regional policy and the course of designing an integrated approach to the development of the functional area. The study consists of two parts. The first presents a new approach to the regional policy in the European Union (EU) and the essence of a functional area, which is an instrument of this policy. The second 
presents the role and the process of designing an integrated concept for the development of a functional area.

It was the Functional Area of Oder Communes that was used by the authors as the object of the study. The article is based on own experiences and reflections arising from the work in the team for the development of a strategy for this area. The work on the creation of the development concept was carried out within the scope of the project „The Socio-Economic Development of the Oder Communes" co-financed by the Programme of the Ministry of Regional Development "The development of towns by strengthening competences of local government units, the social dialog and cooperation with representatives of the civil society" and by the Financial Mechanism of the European Economic Area and/or the Norwegian Financial Mechanism.

\section{LITERATURE REVIEW}

\subsection{New APPROACH TO THE EU REgIONAL POLICY}

In the recent years, Europe has been discussing measures that should be considered to make the regional policy more effective. In addition, the measures had to target desired objectives, foster the socio-economic and territorial cohesion and simultaneously improve the competitiveness of regions as well as respond to current developmental challenges.

The regional policy conducted since the 1970s has been focused on redressing the interregional imbalances and the sectoral approach. The local development was defined as „actions for the social and economic development of a given territorial unit (a town, a commune) with the use of its resources, with respect to the needs of the population and with its involvement in actions taken" (Parysek, 1995, p. 12). The effectiveness limited in relation to the objectives of this policy provoked criticism in many different studies, e.g. the Fourth progress report on cohesion (COM (2006) 281 final), Green Paper on Territorial Cohesion Turning territorial diversity into strength (COM (2008) 616 final), and An Agenda for a Reformed Cohesion Policy. A placed-based approach for meeting European Union challenges and expectations (Barca, 2009). The criticism resulted in conclusions on the need to refocus the EU regional policy. The regional policy conducted in the EU in the recent years has been evolving from the model of the redistribution policy, focusing on transferring funds to the most disadvantaged regions, to the policy focused on the use of endogenous potentials and specifics of individual territories (Wasiluk \& Daniluk, 2013).

The main document indicating the relevance of the territorial approach to the EU regional policy was a report drawn up by Barca, which on the one hand pointed out weaknesses of the cohesion policy, often associated with the sectoral thinking, and on the other hand described the so-called territorial approach to the regional policy (Barca, 2009). As a result of the studies, a new paradigm of the regional development and a new concept for the territoriallyoriented regional policy in the $\mathrm{EU}$ were introduced since 2009.

According to Markowski, the territorial dimension of the development policy stems from the role, which is assigned to the dynamic functional spatial structures. It is by building such structures that the territorial capital is created and is understood as „specific external benefits generated and available as a result of multifunctional user interaction on a relatively isolated territory" (Markowski, 2011, pp. 25-44). It is closely related to the ability to cooperate with local government units in functional areas and with a high level of social trust. Temporary coalitions of local self-government units are created within the framework of functional connections formed and actions for executing development projects are integrated. The territorial capital is a set of elements, which constitute the competitive potential of the region. They include natural resources, public goods, private and mixed goods, human, social and relational capital, organisational resources, relational and cognitive abilities (Capello et al., 2011, pp. 144-145). The concept of building a territorial capital in functional areas requires integrated development planning, which is a prerequisite for the improvement of markets and implementation of the sustainable development paradigm based on the principle of the mutual, balanced relationship among economic, social and environmental subsystems.

Building the concept of the integrated development provides benefits in social and economic terms. It allows for the activation of a community through adoption of a more proactive attitude towards sustainable development by residents, which supports the development of the civil society. From the 
economic point of view, the advantage of this approach is that it places the economic activity on the territory, and the undertaken economic activity depends on the specific economic conditions and comparative advantages of the territory. As a result of the involvement of local stakeholders and rooting of the economic activity in the given territory, it contributes to the overall improvement of the quality of work (Christopherson, 2008, pp. 241-242). The integrated development concept is, therefore, an instrument to overcome administrative barriers in order to use potentials arising from the new resource, which is the territorial capital, including the relational capital.

The EU regional policy is shaped under the influence of various theoretical concepts, which promote new solutions and mechanisms aimed at stimulating the growth and the development of regions. The new direction in the EU regional policy, i.e. the territorially-oriented development, is based on the achievements of the scientific thought in the field of the regional development focused on the analysis of the spatial dimension of the process of economic development in the recent years. The theoretical basis for programming and implementing the new approach to the EU regional policy consists of different theoretical concepts of regional development, including the concept of the network development (Castells, 2008), the concept of the learning region (Florida, 2000) or the new theory of endogenous growth (Szlachta \& Zaleski, 2009).

In Poland, the new paradigm of the regional policy is reflected in the national strategic documents. They include: The National Strategy of Regional Development: Regions, Towns, Rural Areas (NSRD), (The Ministry of Regional Development, 2010), which was adopted by the Council of Ministers on 13 July 2010, and is the main document of the regional policy of the government as one of nine so-called integrated strategies and The National Spatial Development Concept 2030 (NSDC 2030), (The Ministry of Regional Development, 2012), adopted by the Council of Ministers on 13 December 2011, which is the basis for spatial planning policy of the country.

It was in the NSDC 2030 that a new category of functional planning was introduced: ,the separate sectional planning category due to the need to provide planning for the areas with specific characteristics, unrelated to administrative restrictions, regardless of the existence of national, provincial or local plans (plans for functional areas)", (The Ministry of
Regional Development, 2012, p. 18). The principle of dynamic zoning and the designation of planning areas are indicated as a basis for functional planning in order to use local and regional potentials and minimize conflict situations (The Ministry of Regional Development, 2012, p. 68). According to the new paradigm, the local development is the result of joint actions of the public, private, and social sectors.

\subsection{Functional Area of Oder Communes - A NEW CATEgory OF THE REgIONAL AND SPATIAL POLICY}

The NSDC 2030 introduces the concept of the functional area, its types and specifies, who is responsible for their appointing and according to which criteria.

The definition of functional areas formulated in the NSDC 2030 is based on the definition of "the problem area" taken from the Law on Planning and Spatial Development (Dz. U. 2003 nr 80 poz. 717 z późn. zm., art. 2 pkt 7) which defines it as an „area of a particular phenomenon from the scope of spatial economy or appearing spatial conflicts" indicated in the spatial development plan for the province or referred to in the study of conditions and directions for spatial development. Due to the fact that this definition does not exhaust the concept of the functional area, the NSDC 2030 adds the following: "a compact spatial arrangement consisting of functionally related areas characterized by common conditions and expected, uniform development objectives" (The Ministry of Regional Development, 2012, p. 178).

It is in the NSDC 2030 that several types of functional areas were distinguished, which can be represented in three groups (Fig. 1).

Urban functional areas (UFA) are continuous settlement systems, composed of separate administrative units and covering closed areas of towns and functional urban zones associated with them. Administratively, these areas may include both town, rural and urban-rural communes. UFA can be divided into four categories: 1) provincial centres, including metropolitan ones, 2) regional, 3) subregional and 4) local (The Ministry of Regional Development, 2012, pp. 187-191).

Rural functional areas are divided into two groups: 1) participating in the development processes and 2) requiring support for development processes. The first group includes the areas situated in the zone 


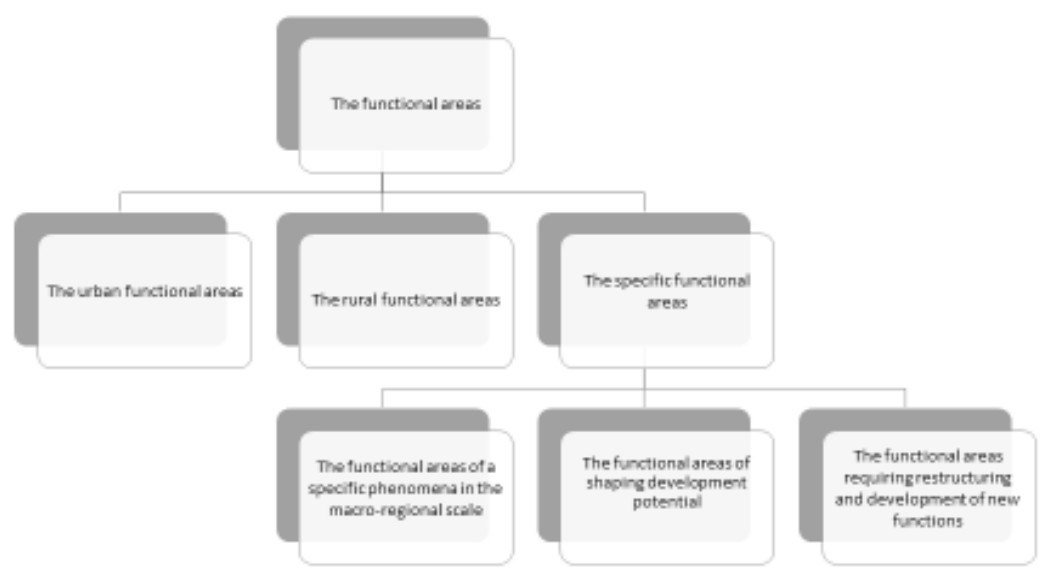

Fig. 1. Types of functional areas

Source: author's elaboration on the basis of (The Ministry of Regional Development, 2012, pp. 181-206).

of a strong impact or in the vicinity of main urban centres; they are characterized by a high share of nonagricultural functions or highly efficient agriculture, rather good access to public services and higherorder services. While the second group includes the areas with low availability of basic public services or situated in the vicinity of urban centres, which have lost their formerly important economic functions as a result of development processes and the dominant agricultural function does not provide sufficient revenue, and those, where commuting to work takes more than 90 minutes (The Ministry of Regional Development, 2012, pp. 191-193).

A specific functional area is a term proposed by the authors for the group of the other three types of functional areas (The Ministry of Regional Development, 2012, pp. 193-206):

- the functional areas of a specific phenomenon in the macro-regional scale (they are divided into seven groups: the coastal zone, Żuławy, mountain areas, closed areas, the Polish exclusive economic zone at sea, soil protection for purposes of agricultural production, areas exposed to the risk of flooding on a scale of river basins),

- the areas of shaping development potential requiring programming protective actions: these are areas of special cultural or natural value (divided into five groups: environmentally valuable areas, cultural landscape protection areas, areas of protection of water resources, areas of strategic mineral deposits),

- the functional areas requiring restructuring and development of new functions supported by the instruments of the appropriate regional policy are the areas with specific concentration of socioeconomic problems, including towns, which may be important for the country (they are divided into 5 groups: The areas with the lowest development level and deteriorating development perspectives, towns and other areas losing existing socioeconomic functions, the areas with the lowest access to services determining development opportunities, border areas, areas with the lowest availability of transport to centres of voivodships).

An example of an initiative, which is a new approach to the EU regional policy is the Functional Area of the Oder Communes (FAOC). The area is located in the Lubusz Voivodship; it is created by three communes: the urban and rural commune of Czerwieńsk, the urban and rural commune of Sulechów, and the rural commune of Dąbie. The FAOC is situated along the main navigable river of the country, Oder, in the natural environment unspoiled by human activity and entirely within the Zielona Góra agglomeration. Given the document that delineates the boundaries of the functional areas of the Lubusz Voivodship (Raport metodyczny..., pp. 13-78), the FAOC can be classified into the following functional areas:

- rural functional areas participating in development processes,

- the functional areas of a specific phenomenon on the macroeconomic scale: areas exposed to the risk of flooding in the scale of river basins, 
- areas of shaping the development potential: environmentally valuable areas,

- areas of shaping the development potential: cultural areas,

- areas of shaping the development potential: protection areas and areas of shaping water resources,

- the functional areas requiring the development of new functions using the instruments of the competent regional policy: border areas.

However, it should be noted that the FAOC was defined even before drafting the document mentioned above within the framework of the project "Socioeconomic development of the Oder communes". The purpose of the project was to develop a model for the Partnership of Oder Communes, which would make it possible to implement projects, which would contribute to the social and economic development of the defined functional area and to strengthening local social ties.

One of the first tasks was therefore to develop a concept for the FAOC development.

\section{RESEARCH METHODS}

The creation of the concept for the FAOC development required integrated planning understood as a holistic process of setting goals and finding ways to achieve the goals set in this process, taking into account the most important interdependencies (relationships) amongst the most important elements in the controlled system.

The model for the creation of the Integrated Strategy for the Development of the Functional Area of Oder Communes consisted of two main parts: strategic and management. The strategic part included the following stages: (1) the diagnosis of the Functional Area of Oder Communes, (2) the analysis of the conditions and the main development trends in the functional area (SWOT) and identification of strategic problems, (3) the definition of the mission and vision of the development, (4) the identification and prioritization of the development goals of the functional area, (5) the assessment of compliance with strategic documents, and (6) the definition of actions for implementation of the plan. The management part related to the management system for the implementation of the strategy and included monitoring and updating the strategy. This concept was created on the basis of the participatory-expert method, in which representatives of the public, social and business sectors participated.

In the first stage, the creation of the concept for development required a diagnosis of the current situation, which would contain the data showing the current demographic and socio-economic situation, the condition of the technical and social infrastructure, and the financial potential of the functional area. It was in the diagnosis that the internal conditions for development were also taken into account. At this stage, both the secondary and primary sources of information were used. The analysis of the source documentation of individual partners, public registers, administrative data and others was carried out. At this stage, the ratio analysis and benchmarking method were applied. Furthermore, such methods of obtaining primary data were used as: participatory observation, non-standardized interview with representatives of the regional and local authorities, subsidiary bodies and other stakeholders of the partnership as well as an online survey addressed to residents of the functional area aimed at evaluation of the quality of life.

The analysis of the functional relations within the scope of public and market services within the area and the existing relational relationships was carried out. The partnership cooperation in the Oder areas was established in order to improve the quality of life of the population living in the area as well as to stimulate the economy; nowadays, it brings together entities from three sectors (public, social and economic). The potential of a functional area consists of not only the potential of the participants in the partnership but also the value added, which is the result of a unique partnership. In the future, it should enable the integration within the scope of the provision of public services in order to use the economies of scale, while improving the quality and availability of services. The diagnostics measures should be repeated on a regular basis in the future, which should enable the verification of the implementation of the objectives and monitoring changes, which will occur on a given territory on the background of its surroundings. The development should not be perceived only in terms of the end result (desired in the static sense), but should be considered as a process of creating new conditions for development (desired in the dynamic sense). These conditions are crucial for changes needed for updating strategy (Kogut-Jaworska, 2011, p. 139).

An analysis of trends, phenomena and development processes was carried out in order to determine the strengths, weaknesses, opportunities, and threats, i.e. 
the SWOT analysis, which allowed for the assessment of the current and future development situation of the functional area. It was in the integrated approach that the scope of the SWOT analysis was extended and supplemented by an analysis of the relationship amongst partners. Strong internal dependencies were taken into account, which occurred amongst the economic, social and spatial spheres as well as environmental one, which can be perceived as internal opportunities or internal threats to the development, strengthening or weakening the development processes in the area. It is at this stage that the problems, resources, competitive potential and the key features of the partners and the whole partnership were identified. The identification of positive and negative aspects of the current situation was carried out, and the main problems in terms of the strategic conclusions were identified.

Then, the mission and vision of the development of the functional area were determined. The vision and mission show the desired future partnership and living conditions of the residents. The vision of the functional area is the picture of its future and the target position in the surroundings. It contains a set of integrated aspirations associated with the future of activities of the partners, based on the analysis of the past and present situation. It is, therefore, a product of the historical heritage. The vision of the functional area presents states possible to achieve and creates a basis for determining the overarching objectives for future actions of the communes leading to the execution of the mission of the functional area. Each action of the partner communes should result from the vision of the communes and the functional area as well as it should serve the implementation of the mission of the functional area. The vision of the functional area is a target image of its functioning in the specified timeframe, which is desired to be achieved by authorities and residents of the commune in cooperation with other entities using current and future resources.

An important stage was also the identification and prioritization of the development goals for the functional area using the tool, which was the logical framework. While choosing the strategic goals and directions for the development, the principle of the sustainable development was applied, which requires providing the balance and sustainability of the development in the economic, social and environmental sphere. The resulting goals meet the SMART criteria.

The management system for strategy implementation includes monitoring and updating the strategy and the description of the scope of operational and implementation actions. Good management is strategically important since it allows local governments to anticipate changes in the environment and aims at using appropriate instruments to improve the effectiveness of local governments (Noworól, 2010, p. 57). It is in the territorial management understood integrally that the priority principle, as already mentioned, is understood as internal (amongst stakeholders of the same local self-government unit) and external (amongst units) partnership. There are three basic partnership postulates that result from this principle (Gawroński, 2014, p. 53):

- shared goals,

- mutual communication: full and the free flow of information amongst partners,

- mutual tolerance: acceptance, equality of the entities and transparency.

The integration must occur in the spatial, social, economic, environmental and management dimension. Such measures are intended to contribute to the creation of competitive advantage of the specific unit of the local self-government, which should result in its development and improvement of the living conditions of the residents by increasing access to public services and raising their quality.

\section{RESEARCH RESULTS}

The substantive activities related to the creation of the concept for the development of the Functional Area of Oder Communes were planned according to the intervention logic, which consists of three levels, which differ in the degree of detail of the issues under discussion.

- The first level: the Integrated Development Strategy for the Functional Area of Oder Communes, which sets development priorities, strategic, operational and general goals as well as general ways of their implementation by all partners.

- The second level: the integrated sectoral strategies in the areas identified by the analyses performed, which provide the best prospects for the development of the functional area or require an intervention:

- the Integrated Program for Activation and Social Participation in the Functional Area,

- the Integrated Strategy for Development of Education and Labour Market in the 
Functional Area,

- the Integrated Strategy for Development; Offers for Free Time in the Functional Area, with particular regard to the Recreational and Environmental Protection Offer. operational objectives were included.

Individual strategic goals will be achieved through the implementation of strategic actions, which are presented in the form of logical frameworks. They include not only actions but also planned effects.

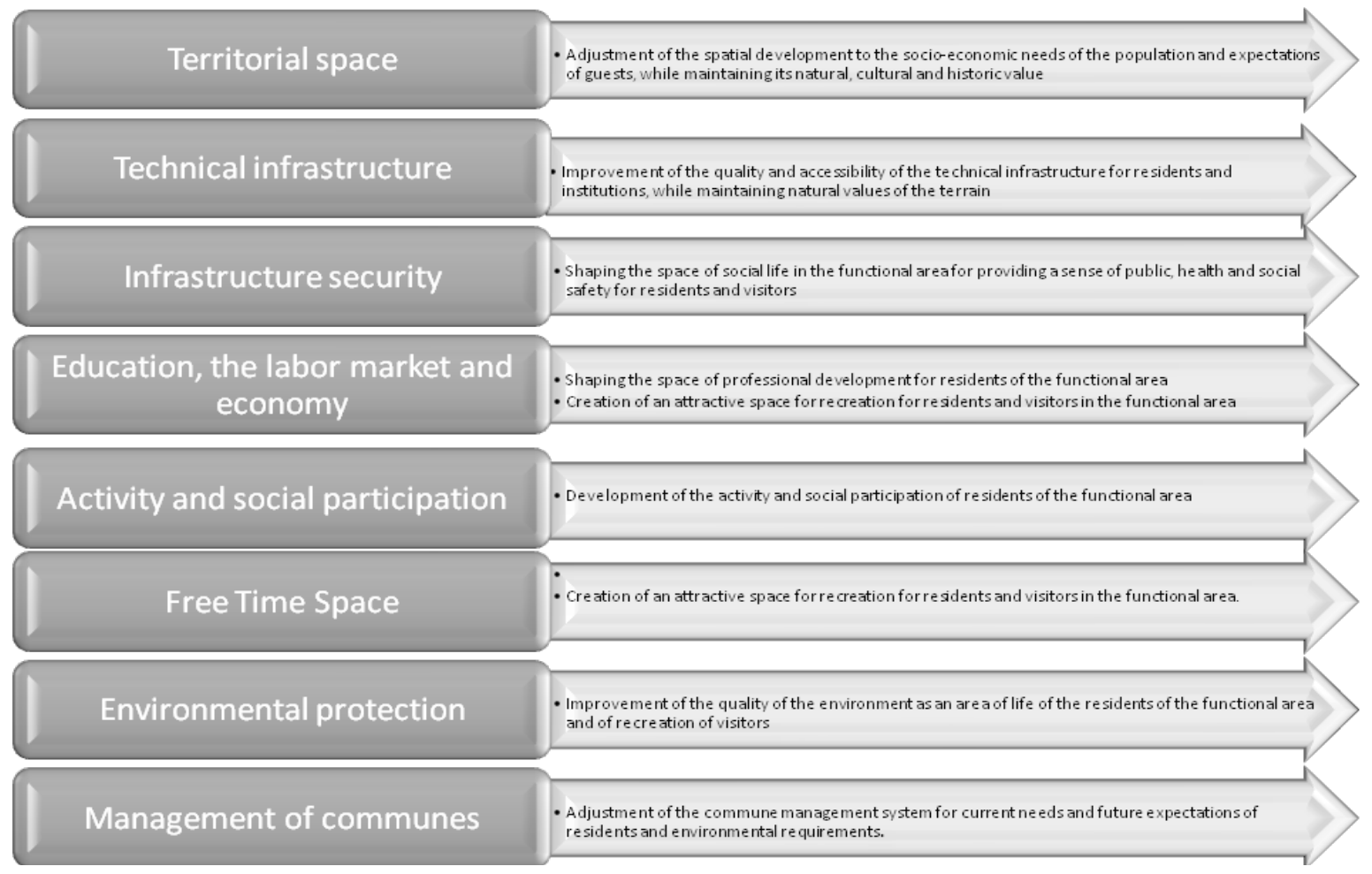

Fig. 2. The structure of priorities and strategic goals for the Functional Area of Oder Communes

Source: author's elaboration on the basis of (The Integrated..., 2015).

- The third level: the operational and implementation documentation for sectoral strategies, which contribute to the reduction of development barriers and substantial use of the endogenous potential of the functional area, including the preparation of the list of recommendations for economic policy, to achieve good growth rates.

The first level was the most important, within the scope of which the priorities and goals were set as a set of interrelated aspirations and the expected results with varying degrees of specificity taking into account the relational potential and resources created as a result of the creation of the functional area. The created set of the specific goals was arranged in a hierarchical structure to facilitate their systematic implementation. The set priorities and goals are a result of a compromise amongst goals of individual partners, opportunities, and limitations. Eight priority areas were found, which were the main areas of analysis and intervention and within the scope of which, nine strategic goals (Fig. 2) and 38
A sample matrix is presented in the Fig. 3.

It was on the second level that the focus was put on three plans, setting the most important problem areas, for which the leading projects and implementation documentation were created. At the same time, the space development plans for all places in the area, in which the priorities set in the concept for the development were taken into account, were prepared.

The socio-economic development of FAOC is impossible without adequate funding. An important role in the development of the area was played by the funds (Eur 365190) obtained for the implementation of the project The Socio-Economic Development of the Oder Communes, which were used to finance:

- preparation of local development plans for the towns located in the functional area,

- preparation of the technical documentation for construction of the water and sewage infrastructure in the area of the Dabie municipality (including cost estimates and environmental decisions), 


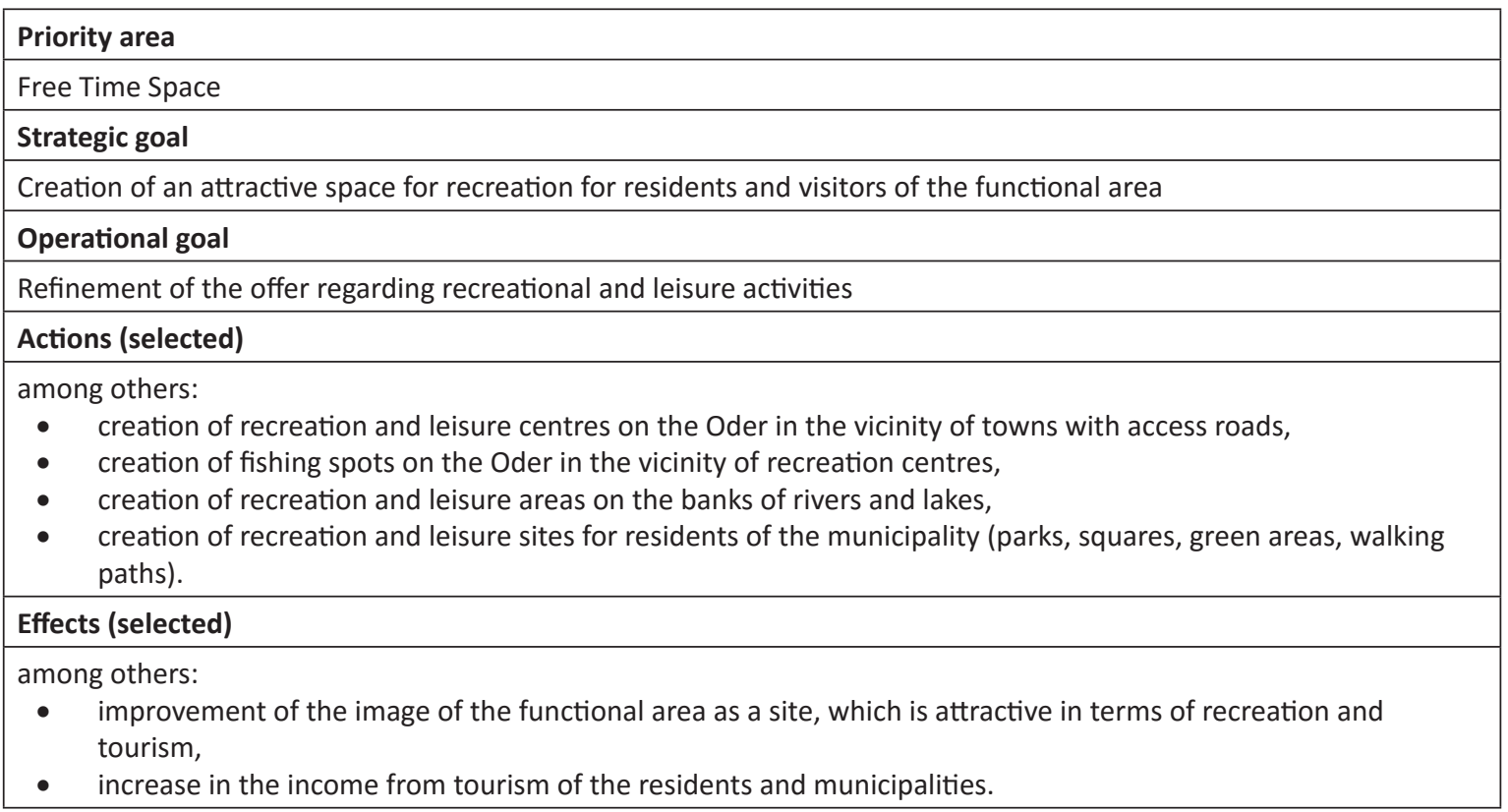

Fig. 3. Logical framework of the operating objective

Source: author's elaboration on the basis of (The Integrated..., 2015).

- preparation of the municipal register of monuments for the entire functional area along with proposals for touristic use of cultural objects.

The source of funding for strategic actions indicated in the FAOC development concept is created by public funds (JST own funds, funds of the national budget, EU funds), private funds (funds of entrepreneurs, residents, etc.) and public-private funds (a combination of public and private investment under Public-Private Partnerships, Licensing Agreements, etc.). The scope of financing of individual actions will depend on their nature. Due to the formal limitations imposed on the article (limited number of pages), the sources of financing of strategic actions of the FAOC development will be the subject of analysis and evaluation in subsequent publications.

The presented concept of the FAOC development was included in The Integrated Development Strategy for the Functional Area of Oder Communes, which was adopted by resolutions of the Municipal Councils of individual local government units in the fourth quarter of 2015. The actual evaluation of the impact of the activities planned in the strategy on the local and regional development will be possible in the near future during monitoring and the evaluation, which will be completed by the end of the first year of the implementation of the strategy. Also, due to the short time of operation of the Functional Area of the Oder Communes, it is difficult to evaluate it as a tool of regional policy, and it will become a subject of further publications in the future.

\section{CONCLUSIONS}

A functional area is a separated area characterized by common geographical and spatial conditions, a system of functional relationships and development objectives defined on the basis of the conditions mentioned above, which ensure the efficient use of the space.

An example of an area defined in this way is the Functional Area of Oder Communes (FAOC), which consists of three communes of the Lubusz Voivodship (Czerwieńsk, Sulechów, Dąbie) located along the main navigable river of the country, Oder.

The article demonstrates the essence of a functional area as a new tool of the EU regional policy and the course of designing an integrated approach to the development of the Functional Area of Oder Communes.

The substantive activities related to the creation of the concept for the development of the FAOC were planned according to the intervention logic, which consists of three levels, which differ in the degree of detail of the issues under discussion.

The first level is the Integrated Development Strategy for the Functional Area of Oder Communes, which sets the development priorities, strategic, operational and general goals as well as general ways of their implementation by all partners.

The second level are three integrated sectoral strategies (The Integrated Program for Activation and 
Social Participation in the Functional Area, The Integrated Strategy for Development of Education and Labour Market in the Functional Area, The Integrated Strategy for Development; Offers for Free Time in the Functional Area, with particular regard to the Recreational and Environmental Protection Offer) in the areas identified by the analyses performed, which provide the best prospects for the development of the functional area or require an intervention.

The third level is the operational and implementation documentation for sectoral strategies, which shall contribute to the reduction of development barriers and substantial use of the endogenous potential of the functional area, including the preparation of the list of recommendations for economic policy, to achieve good growth rates.

\section{LITERATURE}

Barca, F. (2009). An agenda for a reformed cohesion policy. A place-based approach to meeting European Union challenges and expectations. Retrieved from http:// www.europarl.europa.eu/meetdocs/2009_2014/ documents/regi/dv/barca_report_/barca_report_ en.pdf

Capello, R., Fratesi, U., \& Resmini, L. (2011). Globalization and Regional Growth in Europe. Past Trends and Future Scenarios. Advances in Spatial Science. Berlin, Germany: Springer.

Castells, M. (2008). Społeczeństwo sieci [The Network Society]. Warszawa, Poland: PWN.

Christopherson, S. (2008). Local and regional development. Economic Geography, 84(2), 241-242.

Commission of the European Communities. (2008). Communication from the Commission to the Council, the European Parliament, the Committee of the Regions and the European Economic and Social Committee, Green Paper on Territorial Cohesion Turning territorial diversity into strength, $\operatorname{COM}(2008) 616$ final. Retrieved from http://eur-lex.europa.eu/LexUriServ/ LexUriServ.do?uri=COM:2008:0616:FIN:EN:PDF

Commission of the European Communities,. (2006). The Growth and Jobs Strategy and the Reform of European cohesion policy. Fourth progress report on cohesion, $\operatorname{COM}(2006) 281$ final. Retrieved from http:// ec.europa.eu/regional_policy/sources/docoffic/ official/reports/pdf/interim4/4inter_en.pdf

Florida, R. (2000). The Learning Region. In Z. J. Acs (Ed.), Regional Innovation. New York, USA: Knowledge and Global Change.
Gawroński, H. (2014). Zintegrowane zarządzanie jednostkami terytorialnymi w perspektywie finansowej 2014-2020 [Integrated management of territorial units in the financial perspective 20142020]. Rozprawy Naukowe i Zawodowe Państwowej Wyższej Szkoły Zawodowej w Elblagu, 18, 51-67.

Kogut-Jaworska, M. (2011). Opracowanie i aktualizacja strategii rozwoju województwa w kontekście nowych zasad prowadzenia polityki rozwoju [The regional development strategy drawing up and updating in the context of the new principles of development policy]. Zeszyty Naukowe Uniwersytetu Szczecińskiego, Ekonomiczne Problemy Usług, 77(683), 137-149.

Markowski, T. (2011). Funkcjonowanie gospodarki przestrzennej - założenia budowy modelu zintegrowanego planowania i zarządzania rozwojem [The functioning of the spatial development Foundation construction of the model of integrated planning and development management]. In $\mathrm{T}$. Markowski, \& P. Żubr (Eds.), System planowania przestrzennego i jego rola w strategicznym zarządzaniu rozwojem kraju. Warszawa, Poland: Studia KPZK PAN.

Ministerstwo Rozwoju Regionalnego [The Ministry of Regional Development]. (2012). Koncepcja Przestrzennego Zagospodarowania Kraju 2030 [National Spatial Development Concept 2030].

Ministerstwo Rozwoju Regionalnego [The Ministry of Regional Development]. (2010). Krajowa Strategia Rozwoju Regionalnego 2010-2020: Regiony, Miasta, Obszary Wiejskie [National Strategy of Regional Development 2010-2020: Regions, Cities, Rural Areas]. Retrieved from https://www.mr.gov.pl/media/3337/ KSRR_13_07_2010.pdf

Noworól, A. (2007). Planowanie rozwoju terytorialnego $w$ skali regionalnej i lokalnej [Territory development planning in regional and local scale]. Kraków, Poland: Wydawnictwo Uniwersytetu Jagiellońskiego.

Noworól, A. (2010). Zarządzanie w samorządzie [Management in Local Government]. In B. Imiołczyk (Ed.), $A B C$ samorzadu terytorialnego [ABC Local Government $]$. Warszawa, Poland: Fundacji Rozwoju Demokracji Lokalnej.

Parysek, J. (1995). Rola samorządu terytorialnego w rozwoju lokalnym [The role of the local government in local development]. In J. Parysek (Ed.), Rozwój lokalny, zagospodarowanie przestrzenne $i$ nisze aktywności gospodarczej [Local development, spatial development and economic activity]. Warszawa, Poland: PWN.

Raport metodyczny określający metodyke badania $i$ dobór kryteriów delimitujących obszary funkcjonalne województwa. Wstępna wersja obszarów funkcjonalnych wraz $z$ obszarami strategicznej interwencji. Zielona Góra, Poland: Urząd Marszałkowski Województwa Lubuskiego. Retrieved from http://www.bip.lubuskie.pl/ system/obj/26652_wstepna_wersja_obszarow_ funkcjonalnych_wraz_z_obszarami_strategicznej_ interwencji_30.09.2015.pdf 
Rosenkiewicz, K. (2012). Obszary funkcjonalne jako nowa koncepcja polityki regionalnej i polityki przestrzennej w Polsce [Functional areas - a new category of regional policy and spatial development policy in Poland]. Rozwój Regionalny i Polityka Regionalna, 17-18, 71-88.

Szlachta, J., \& Zaleski, J. (2009). Spójność terytorialna w kontekście reformy europejskiej polityki strukturalnej - operacjonalizacja wymiaru terytorialnego [Territorial Cohesion in the Context of the Reform of the EU Structural Policy - Making Territorial Dimesion Operational]. In Spójność terytorialna wyzwaniem polityki rozwoju Unii Europejskiej. Polski wkład $w$ debate [Territorial Cohesion as a Challenge of the EU Development Policy. Polish Contribution to the Debate]. Warszawa, Poland: Ministerstwo Rozwoju Regionalnego.

Ustawa z dnia 27 marca 2003 r. o planowaniu i zagospodarowaniu przestrzennym, Dz. U. z 2003 r., nr 80 poz. 717, z późn. zm. [Act of 27 March 2003 - about spatial planning and development, Journal of Laws, No. 80, item 717, as amended].

Wasiluk, A., \& Daniluk, A. (2013). The possibilities of creating cross-border clusters. Vilnius, Lithuania: Vilnius University Publishing House.

Zintegrowana Strategia Rozwoju Edukacji i Rynku Pracy na terenie Obszaru Funkcjonalnego [The Integrated Strategy for Development of Education and Labour Market in the Functional Area]. (2015). Retrieved from http://www.czerwiensk.pl/asp/pliki/ aktualnosci/rynek_pracy_i_edukacja_wersja_do_ konsultacji.pdf

Zintegrowana Strategia Rozwoju Obszaru Funkcjonalnego Gmin Nadodrzańskich [The Integrated Development Strategy for the Functional Area of Oder Communes]. (2015). Retrieved from http://www.czerwiensk. $\mathrm{pl} /$ asp/pliki/aktualnosci/zsrofgn_strategia_do_ konsutacji.pdf

Zintegrowana Strategia Rozwoju Oferty Czasu Wolnego na terenie Obszaru Funkcjonalnego, ze szczególnym uwzględnieniem Oferty Rekreacyjnej i Ochrony Srodowiska [The Integrated Strategy for Development; Offers for Free Time in the Functional Area, with particularregard to the RecreationalandEnvironmental Protection Offer]. (2015). Retrieved from http://www. czerwiensk.pl/asp/pliki/aktualnosci/zintegrowana_ strategia_rozwoju_oferty_czasu_wolnego_na_ terenie_obszaru_funkcjonalnego.pdf

Zintegrowany Program Aktywizacji i Partycypacji Społecznej na terenie Obszaru Funkcjonalnego [The Integrated Program for Activation and Social Participation in the Functional Area]. (2015). Retrieved from http://www. czerwiensk.pl/asp/pliki/aktualnosci/zintegrowany_ program_partycypacji_do_konsultacji.pdf 